\title{
Literacy Acquisition: A Plus Factor in French Children's Word Segmentation After 5 Years of Age
}

\author{
SAMANTHA RUVOLETTO \\ Lorraine University
}

\begin{abstract}
Liaison (les[z]ours [le.zuss], 'the bears') and enchaînement (une[n]autruche [y.no.tьy], 'an ostrich') are two French phenomena of re-syllabification which entail children's errors in segmentation. Even though re-syllabified words are perceived blended, in writing they appear separated by graphic markers ('les ours', 'une autruche'). The current study aims to understand the frequency effect and the influence of literacy acquisition in word segmentation by a picture naming task and a writing task testing the same group of 37 children (in a primary school in France from 6:4 to 7:6) at three time periods (pre-readers, beginning readers and readers). Results revealed no frequency effects but a clear contribution of basic skills necessary to writing and reading activities in word segmentation.
\end{abstract}

Keywords

French language, re-syllabification, written form, word boundaries, literacy, factor, lexical consonant, liaison consonant

\section{Introduction}

In this article, we establish a link between literacy and French children's word segmentation. We refer to literacy as a set of skills necessary to basic writing and reading activities which are developed in school (e.g. to know how to associate a phoneme to grapheme and recognized written lexical boundaries). These skills are also known as Word Study (Pinnell \& Fountas, 2004). Before analyzing the role of literacy, we will describe word segmentation in French-speaking children. Then, we will focus on liaison and enchainment as phonological phenomena, analyzing their implications in children's identification of word boundaries.

\section{How Children Identify Word Boundaries and Segment Speech}

The identification of word boundaries in continuous speech is one of the most important skills that children must master to perform in language. According to the 'rhythmic segmentation hypothesis' (Nazzi, Iakimova, Bertoncini, Frédonie \& Alcantara, 2006), infants use various acoustic cues depending on the phonological characteristics of their first language to obtain accurate segmentation. Therefore, "segmentation differs according to the global rhythmic properties of one's native language (Nazzi, Iakimova, Bertoncini, Frédonie \& Alcantara, 2006, p. 85). English-speaking children use prosodic cues, such as the alternation of stressed and unstressed syllables (Cutler \& Carter, 1987; Cutler \& Norris, 1988) and trochaic units (Jusczyk, Houston \& Newsome, 1999; Curtin, Mitz \& Christiansen, 2005), while Japanese children employ moraic units (Cutler \& Otake, 
1994) to identify the beginning of words. Differing from these languages, French has a syllable-based prosody (Delattre, 1965; Pulgram, 1970; Kaye \& Lowenstamm, 1984; Béchade, 1992; Di Cristo, 1998). As a consequence, French-speaking children focus not only on distributional cues but also on syllabic regularities to identify word boundaries (Goyet, Schonen \& Nazzi, 2010; Nazzi, Iakimova, Bertoncini, Frédonie \& Alcantara, 2006; Saffran, Newport \& Aslin, 1996b). Babineau and Shi (2011) tested perception in a group of French infants aged 20 to 24 months old. Results showed that infants 'relied on the syllabic edges to find word boundaries, i.e. a strong bias for syllabic integrity at this age' (p. 6), concluding that French children preferred to use syllabic units rather than distributional cues to segment speech. The productions of two-year-olds' monosyllabic

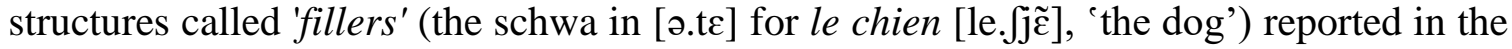
literature (Bassano, Maillochon \& Mottet, 2008; Braud, 2003; Demuth \& Tremblay, 2008; Dugua, Chevrot \& Fayol, 2006; Wauquier-Gravelines, 2004) confirmed a perception and a segmentation based on syllabic units. Children who have not already acquired the set of French articles, perceive article+noun sequences as a bisyllabic word stressed on the second syllable (Pulgram, 1970). To fill the first syllabic unstressed position, they produce the so-called fillers, some units specified phonologically and prosodically but underspecified morphologically. A segmentation based on syllabic units entails many difficulties for French infants especially in case of two frequent re-syllabification processes: liaison and enchaînement.

\section{The Two Phonological Phenomena: Liaison and Enchaînement}

Liaison is an obligatory external sandhi happening in article+noun (e.g. les + ours, 'the+bears') or adjective+noun (e.g. petit+ours, 'small+bears') syntactic structures between two words: a word on the left called 'word1' and a word on the right, called 'word2'. Word 2 is always a vowel-initial word (e.g. word1 les [le], 'the' + word 2 ours [иьs], 'bear' $\rightarrow$ les [z]ours [le.zuьs], 'the bears' vs. word1 les [le] + word2 fleurs [flœь] $\rightarrow$ les[Ø]fleurs [le.flœь], 'the flowers'). Many phonological studies tried to define the phonological phenomenon (Côté, 2014 for a resumé). Autosegmental phonological studies based on oral data (Encrevé, 1983; Wauquier, 2013) defined liaison as a phonological process where first, a latent segment (called liaison consonant, LC) surfaces (typically, the

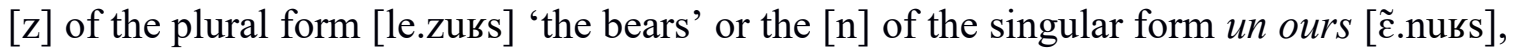
'a bear'); next, the LC is re-syllabified and becomes the onset of the noun, modifying the nominal syllabic structure which normally begins with a vowel nucleus (e.g. ours [uss] 'bear' vs. les ours [le.zuss], 'the bears').

A LC and an initial consonant has not the same phonological representation in autosegmental phonology. Figure 1 and Figure 2 show two different phonological autosegmental representations: Figure 1 displays the representation of a liaison les [z]amis [le.za.mi] ('the friends'); Figure 2 shows the representation of a non-liaison sequence where an article is followed by a consonantal initial word les zéros [le.zе.во] ('the zeroes'). In autosegmental phonology, the underlying and surface forms consist of parallel strings of segments arranged in two or more tiers (Goldsmith, 1990). In Figures 1 and 2, three tiers are represented: the syllabic tier on the top, which displays the syllabic positions (the string of 'A' and ' $\mathrm{R}$ ' which stand for the French word Attaque, Eng. 'onset' and Rime, Eng. 'rhyme'); the segmental tier on the bottom, which displays segmental information (the phones who composed the words [lezami] or [lеzевэ]); the skeletal tier which allows the 
connections between the two other tiers thanks to a series of skeletal nodes (the dots on the figures). In Figure 1, from Wauquier and Braud (2008), the LC [z] is represented as a floating segment with respect to both the skeletal and syllabic tiers, as it is connected by a dotted line to a skeletal slot and to a syllabic onset position (the ' $A$ '). Liaison representation differs from a consonant-initial noun representation. In Figure 2, the initial consonant [z] of word2 is grounded to the skeletal position but also to the syllabic position of the onset. Then, the $[\mathrm{z}]$ is not a floating segment.

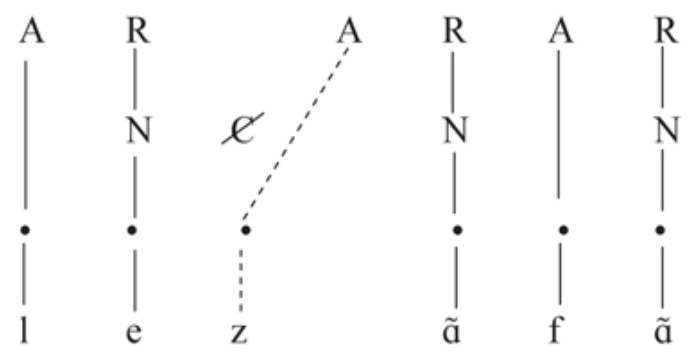

Figure 1. Phonological répresentation of liaison les amis [le.za.mi], 'the friends' (Waquier and Braud, 2008)

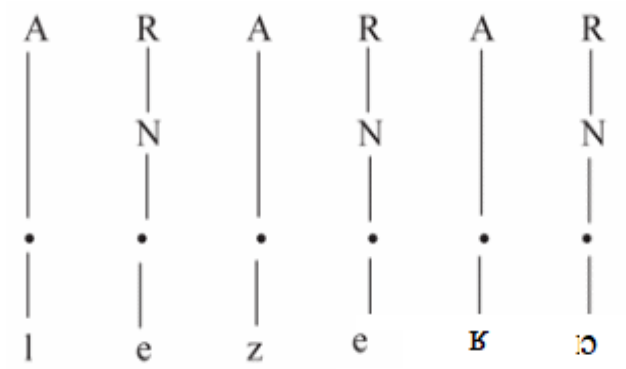

Figure 2. Phonological representation of consonant-initial word les zéros [le.ze.во], 'the zeroes'

The process of enchainement has some points in common with liaison; it involves word1+word 2 syntactic structures article+noun and adjective+noun. Moreover the last consonant of word1 is re-syllabified into the following word2 (e.g. word1 petite [po.tit],

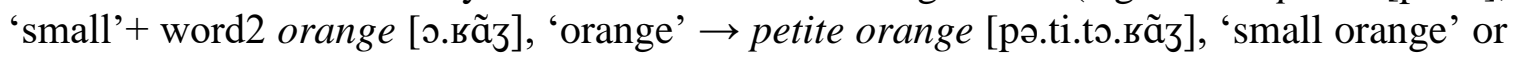
word1 une [yn] 'an' + word2 autruche [ot.6yf], 'ostrich' $\rightarrow$ une autruche [y.no.tsyf], 'an ostrich'). Nonetheless these two phenomena are different phonologically. According to the literature (Encrevé, 1988) in enchaînement the re-syllabified consonant is not a latent segment, and would be produced by the speaker even if enchaînement is not realized (e.g.

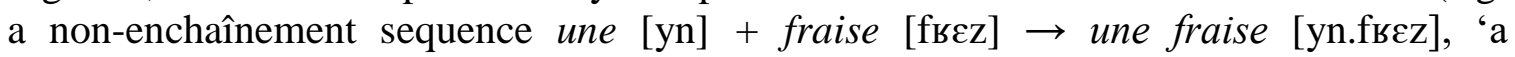
strawberry'). For this reason, this consonant is not a floating segment (as the $[\mathrm{z}]$ in Figure 1) but a 'fixed consonant' (FC). Figure 3 shows the autosegmental representation from Encrevé (1983) of the word1 avec [avek], (Eng. 'with'), where the [k] is a FC. The FC is not double-floating as the LC in Figure 1 but it is anchored to the skeletal position. Moreover, it is not linked to the syllabic position as the lexical consonant [z] in Figure 2. 
The fact that FC is not anchored to a syllabic position, allows the link to the following syllabic empty onset if word2 starts with a vowel (Figure 4). This process entails the resyllabification.

avec

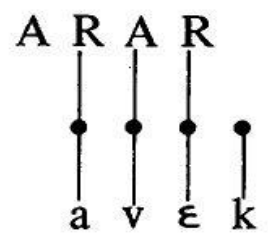

Figure 3. Phonological representation of the word1 avec [avek], 'with' (Encrevé, 1983, p. 57)

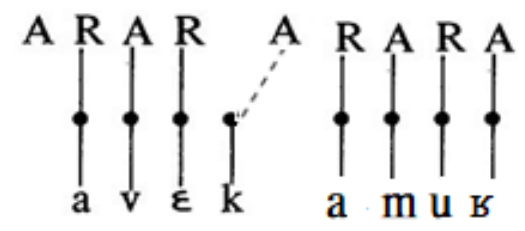

Figure 4. Phonological representation of the enchâinement of avec[k]amour [ave.ka.mus], 'with love'

Despite the phonological representations and theories, the two phenomena involve a two-word sequence (word1+word2) where word2 starts with a vowel. These contexts entail the re-syllabification of the final consonant of word1 (whether pronounced or latent, LC or FC), which becomes the onset of the first syllable of word2, thereby altering the syllabic structure of word 2 as its left lexical boundary gains a consonant onset. Consequently, vowel-initial nouns display two possible syllabic structures: one if resyllabification occurs ( $z+$ ours [zuss], $t+$ orage [tэ.вãz]) and the other if it does not, as the noun is produced in isolation (ours [ивs], orage [о.ва̃z]). So the identification of the left boundary of a vowel-initial noun in speech would be more difficult than the identification of another word having a consonantal onset as for this last one only a single syllabic structure is possible (e.g. les fraises [le.fьєz], 'the strawberries' vs. fraise [fьєz], 'strawberry').

\section{Children's Difficulties in French Word Segmentation}

In general, French children use syllabic units to segment speech and are exposed to an adult input characterized by two possible syllabic structures for vowel-initial words. They could therefore show some difficulties in word segmentation.

In a longitudinal study, Chevrot and Fayol (2001) recorded the spontaneous speech of a French-speaking child (Sophie) aged 25 to 42 months old during interactions in a family context. The results showed 276 errors called 'substitution' as le(s)[n]éléphants [le.ne.le.fã] instead of les[z] éléphants [le.ze.le.fã], 'the elephants'. The correct LC [z] was replaced by [n] $(l e(s)[n]$ éléphants [le.ne.le.fã] instead of les[z]éléphants [le.ze.le.fã], 'the 
elephants'). In some productions, she seems to add potential LC consonants ([n], [z] and [t]) between two words (e.g. [papanuss] for papa ours, 'Papa bear'). We could explain these productions considering French segmentation process based on syllabic units. Respecting syllabic boundaries in word segmentation and considering the LC as the

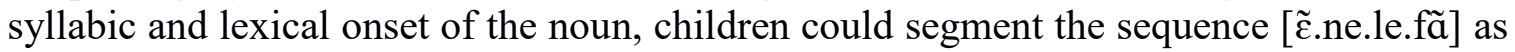
a word $1[\tilde{\varepsilon}]$ plus a word2 [ne.le.fã]. In these cases, the LC [n], which is a syllabic onset, is processed like it was the lexical initial consonant of the noun. So when children have to produce an article+noun plural sequence, they realized the plural article (les [le]) followed by a noun starting with a LC [n], getting the sequence $l e(s)[n]$ éléphants [le.ne.le.fã]. Other studies confirmed the presence of substitutions in children's oral productions aged 2 to 5 years old but in the same way they recorded some occurrences of 'non-realizations' of re-

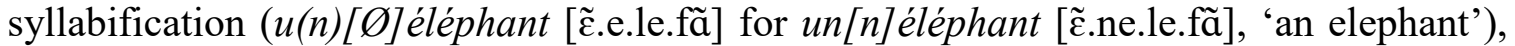
where LC is not produced (Chevrot, Chabanal \& Dugua, 2007; Chevrot, Dugua \& Fayol, 2009; Chevrot \& Fayol, 2001; Nardy \& Dugua, 2011; Wuaquier-Gravelines \& Braud, 2005; Wauquier \& Shoemaker, 2013; Wauquier, 2009; Wauquier, 2010). In these cases children understand that LC is not a word-initial consonant of the noun. They know that word2 (éléphant [e.le.fã], 'elephant') has an initial-vowel in isolation and can be preceded by other consonants in the speech (e.x. l'éléphant [le.le.fã], 'the elephant'). Consequently children could produce article+vowel-initial word juxtaposing word1 and word2 without

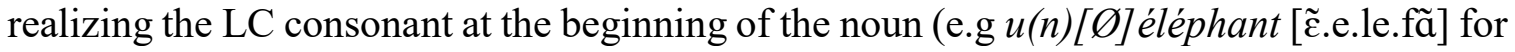

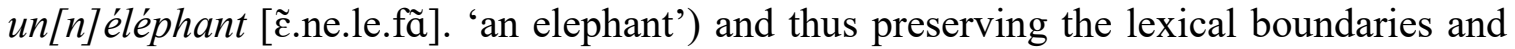
nucleus structure of word2. Substitutions and non-realizations revealed two different developmental patterns. If substitutions seem to vanish by age 6 , 'non-realizations' of resyllabification last beyond 5 years of age (Basset, 2000; Chevrot, Dugua, HarnoisDelpiano, Siccardi \& Spinelli, 2013).

The disappearance of substitution seems to be related to the acquisition of the difference between a LC and a lexical consonant which happened at around age 6. Dugua (2006) tested 200 French speaking children aged 2 to 6 years old classified in 4 groups according to their age $(2-3 ; 3-4 ; 4-5 ; 5-6)$. She designed a picture naming task using cards depicting imaginary animals. First she showed a card and produced: c'est un[n] ivak ('it's a[n]ivak') and asked the children to name the card with two of those imaginary animals. If children said deux nivaks ('two nivaks'), using the [n] as initial consonant of the noun, it means that they considered the word as a consonant-initial word and segmented the sequence respecting syllabic boundaries. If they produced deux-z-ivak ('two-LC-ivaks') they treated the [n] in singular sequence as a LC and the noun as a vowel-initial word. Dugua recorded that children aged 2 to 3 and 3 to 4 segmented the sequences using syllabic units, considering the [n] as the initial consonant of the noun. Children aged 4 to 5 years old proposed two kinds of segmentation: one in which the [n] was the initial consonant of the noun; another one where the [n] was a LC and the noun a vowel-initial word. On the contrary, children aged 5 to 6 processed the [n] as an LC exclusively.

To confirm the results Dugua and Chabanal (2006) tested 4 groups of children aged 2 to $6(2: 4-3: 1 / 3: 2-4: 1 / 4: 2-5: 0$ / 5:2-6:1) by a picture naming task where they had to produce some vowel-initial animal names (écureuil, 'squirrel', éléphant, 'elephant', ours, 'bear') in isolation (ours, viens ici !, 'bear, come here !'). The results showed that younger children produced $35 \%$ of vowel-initial words as consonantal one (zours, nours). The 
percentage decreased according to the increase of the age (19\% at 4 years old; $8 \%$ at 5 years old; $2.8 \%$ at 6 years old).

These results confirm that at age 6 French children knew lexical boundaries and could tell the difference between a lexical consonant and a liaison consonant. However how can we explain this process of acquisition?

The Usage-Based Theory and the Acquisition of Lexical Boundaries in Re-syllabified Sequences

The Usage-based theory designed by Chevrot and Fayol (2001) drawing from Tomasello's works (2003) point out a frequency effect in French acquisition of liaison sequences. According to this theory, children memorize language structures by chunks, organized in abstract schemas holding phonological, syntactical and lexical information. So far re-syllabified sequences are well organized in an abstract schema: for the liaison chunk les éléphants, the schema will be [DETERMINANT-z-[vowel]-NOUN] plural] (Bybee, 2001a). The stability and the availability of chunk schemas depend on their frequency of use in children's language environment (Chabanal \& Liégeois, 2014). A high frequency chunk schema is more stable, available and therefore better produced than a low frequency chunk schema. Consequently, a high frequency re-syllabified sequence holding a stable schema with fixed lexical boundaries, is more easily acquired and fewer errors are produced (Bybee, 2005) than a low frequency re-syllabified.

Considering this explanation, a child might initially learn to liaise a specific construction (e.g. les éléphants) depending on its frequency but not generalize to other vowel initial words. In a recent study, Chevrot et al. (in publication) investigated the frequency effect on re-syllabified sequences testing 120 French-speaking children between 2 and 6 years of age and 36 French-speaking adults by using a detection task. To build this task, they considered that in French some vowel-initial nouns were more frequent in a singular forms than in the plural one (for example the noun avion, 'plane', was more frequent than avions, 'planes') and vice-versa. As a consequence, if a word appeared more frequently in singular forms than in plural forms, for this word a liaison with a LC [n] is more probable (un[n]avion, 'a plane') than a liaison with a LC [z]. Analyzing the occurrences, the frequency and the liaison contexts, it was possible to establish for each test item a high-frequency variant (e.g. for the noun avion, 'plane', the liaison in [n] and the singular form of the noun) and a low-frequency variant (e.g. for the noun avion, 'plane', the liaison in $[\mathrm{z}]$ and the plural form of the noun). In the task, participants had to look at an image representing an object (e.g. a plane). Then they heard a sentence where the name of the object was present or absent. They were asked to answer as quickly as possible "Oui/non" (in English "Yes/no") if the object depicted was pronounced or not in the sentence. Three conditions were created: two test conditions and a control condition. In the two test conditions: (1) the object depicted was presented in its high-frequent variant (e.g. for avion singular form and LC [n], elle a rêvé d'un AVION géant, she dreamed of a giant $P L A N E$ ), (2) the object depicted was presented in its low-frequent variant (e.g. for avion plural form and LC [n], il a vu des AVIONS à l'aéroport, 'he saw some PLANES'). In the control condition, the object was not pronounced in the sentence (e.g. les acrobates étaient impressionnants, 'the acrobats were impressive'). Response times (RTs) were recorded. In children aged 2-5 years, data showed an interaction between the frequency of the variant and the liaison: RTs are slower in low-frequency variant condition than in high-frequency 
variant condition. However, no frequency effect was recorded in children aged 5 to 6 and in adults. To explain these results, the authors proposed that after age 5, oral productions of re-syllabified sequences were no more influenced by frequency than by any other variable such as literacy acquisition and written awareness.

\section{The Role of Literacy in Phonological Representation and Word Segmentation}

Many studies on different languages had already shown that in their first literacy activities, children used oral skills and units to perform reading and writing (Duncan, Seymour \& Hill, 2000; Ziegler \& Goswami, 2005; Burt, 2006; Feifer, 2013). In the same way literacy influences phonological representations and awareness (Seidenberg \& Tanenhaus, 1979; Dijkstra, Fieuws \& Roelofs, 1995; Hallé, Chereau \& Segui, 2000). Moreover researchers have shown the mutual influences of orthographic and phonological competences both in adults (Ehri \& Wilce 1980; Perre, Midgley \& Ziegler, 2009) and children (Goswami, 2000; Ziegler \& Mouneaux, 2007; Nation \& Hulmes, 2011).

Building on the results in the literature, in the current study we examine the influence of writing acquisition on French word segmentation testing a group of French children after age 5. In France, approximately at this age, children begin Primary school. During first grade, they start to learn reading and writing and to develop knowledge of orthographic forms. The word1+word2 sequences that were perceived as blended in the speech, were well-separated in writing by graphic markers, such as a space for liaison (<un éléphant >) and enchaînement (<petite orange>). Moreover, the consonants re-syllabified in oral productions at the beginning of word 2 are written as a grapheme at the end of word1 (e.g. the $\langle$ n $>$ of $\langle$ un $>$ in $<$ un éléphant $>$ ). So we could suppose the awareness of written forms of vowel-initial words and graphic markers might help children to completely set lexical word boundaries. We might think that orthographic forms together with literacy can generate a feedback effect and improve children's phonological skills and oral representations and this allows children to distinguish a lexical consonant from a liaison one. Literacy could already explain the results in the literature concerning substitution errors. In writing, the LC is represented as a consonant at the end of word1 (the $\langle\mathbf{n}\rangle$ in un[n]éléphant; the $<\mathbf{t}>$ in petite[t]orange). Learning how to read and to write word 1 could help children to reduce the number of substitutions.

As previously stated, the only incorrect productions lasting beyond age 5 are the non-realizations of LC (des éléphants [de-e.le.fã]). When children start to learn writing, they also learn to separate words by orthographic markers such a blank between word 1 and word2. Thus, learning to write the sequence des éléphants would not help children to reduce the number of non-realizations. In fact, it could raise it. Just as the two words in written sequences are separated by blank, they could realize it as a pause (silence, no segment content) in speech. So, in the first year of school, we expected a high number of non-realizations of re-syllabification, in liaison (des éléphants [de.e.le.fã]) but also in enchaînement (petite orange [рə.tit.ə.ьãz]).

Following this idea, in the current study we 'rehabilitated' the role of nonrealizations in French acquisition that must be considered not as a wrong production or as an error but as an intermediate stage in the acquisition of lexical forms and word segmentation amplified by literacy.

\section{Hypothesis and Methodology}


In the current study, we analyze the influence of frequency and literacy acquisition on the identification of word boundaries in French. We focused our research on the processes of liaison and enchaînement, which create non-aligned sequences where word boundaries seem not to be perfectly acquired until the age of 6 . We designed our study, testing the same group of children during two school years (from the beginning of the first grade to the second grade) at three time periods (October 2015, June 2015 and January 2016) calling them pre-readers, beginning readers and readers. In these three periods, children presented different literacy skills. At the beginning of this study they were in an early stage of literacy acquisition (pre-readers), then little by little they developed their writing skills (beginning readers) and at the third period they knew how to write and read word sequences (readers).

Firstly, we verified if frequency of words affects the acquisition of re-syllabified sequences after the age of 5 . If word 2 was more frequent in its plural form, compared to the singular form, it means it was also more available in plural sequences (e.g. les[z]éléphants) than in the singular sequences (ex. un[n]éléphant). Consequently, according to the Usage based theory, children could identify word2 as a [z] initial word, producing a higher number of substitutions (un[z]éléphant for un[n]éléphant). According to the literature, we expected no frequency effect at the three points, confirming the necessity of introducing literacy as a variable in word segmentation after age 5.

Secondly, we evaluated the role of substitutions and non-realizations at the three different stages of literacy acquisition. Our starting point was the assumption that the number of substitutions decreases in literate children, in accordance with increased literacy skills. We further assumed that non-realization of re-syllabification reveals awareness of word boundaries. We therefore expected to find a significant number of non-realizations in the early stage of literacy acquisition (pre-readers and beginning readers) and a correlation between the number of these non-realizations and the level of writing acquisition: most of the children who correctly write sequences involve liaison and enchaînement would produce non-realizations orally. In fact, writing these sequences correctly would suggest an association of the orthographic blank with the absence of LC realization and re-syllabification.

If these hypotheses were verified, we could start to consider literacy as a plus factor, which operates in French segmentation after 6 years of age, helping children to acquire the difference between a lexical consonant and a liaison one. Moreover, we could establish a relationship between oral and written forms as the learning of written lexicon can affect the set of phonological representation of lexical and resyllabified consonants.

To verify these hypotheses, we proposed a quantitative analysis of the data recorded by an oral task and a 'writing' task at the three time periods. Comparing the results collected during these three moments allowed us to verify our hypothesis on oral productions concerning the number of non-realizations relating to literacy development. Therefore, we expected different results and patterns from pre-readers to readers; on the one hand a decrease of the number of non-realizations and on the other hand an increase of the number of correct writing of resyllabified sequences. We concluded by a cross-task comparison of the results to establish a link between the two modalities.

\section{Method}




\section{Participants}

Forty-three participants ( 28 girls and 15 boys) were recruited from two first grade classes in a Primary school in the North of France. Social data were systematically collected by parental questionnaires. All children and parents were monolingual French speakers. In our longitudinal study we tested the same group of children at three moments during first grade (October and June 2015) and second grade (January 2016). The same tools and methods were used to teach reading and writing (decoding and encoding) in both classes. Teachers communicated and shared contents during class hours and established together daily programs, goals and tests. For these reasons, we treated all the children as a single group. Most children started to learn reading and writing in first grade, in accordance with the French National program for education (2013-2014). Reading and writing scores were collected thanks to a national standardized test provided by the Minister of National Education at the beginning of first grade. General low scores on this set of tests concerning writing and reading activities (e.g. writing their first name, knowing the French alphabet, discriminating an image from a writing text) are a signal of a potential language disorder. Since our study was not focused on language disorders but on typical language development, we excluded 6 children (13\%) from the research. The thirty-seven participants were tested at three points of their literacy acquisition considering their results on a reading test of 12 sequences of article+noun words (e.g. l'école, 'the school'). When they can read and write simple current words in isolation (such as their first name) they are 'pre-readers' (PR, Mean age 6:4, Standard Deviation=4.71). In an early stage of literacy acquisition where they can read almost $70 \%$ of article+noun test sequences and they are 'beginning readers' (BR, Mean age 7:0, Standard Deviation=4.69). In the last stage when they have developed basic reading skills allowing them to read all the sequences and we can call them 'readers' (R, Mean age 7:6, Standard Deviation=4.69). Participants' data are summed up in Table 1.

Table 1

Participants'data for $P R, B R$ and $R$

\begin{tabular}{|l|c|c|c|}
\hline & $\begin{array}{c}\text { Pre-readers } \\
\text { (PR) }\end{array}$ & $\begin{array}{c}\text { Beginnig } \\
\text { readers (BR) }\end{array}$ & Readers (R) \\
\hline Mean age (y:m) & $6: 4$ & $7: 0$ & $7: 6$ \\
\hline $\begin{array}{l}\text { Standard Deviation } \\
(n=37)\end{array}$ & 4.71 & 4.69 & 4.69 \\
\hline
\end{tabular}

We tested PR, BR and R children by a picture naming task and only BR and R by a writing task. The order of tasks was randomized for each participant.

Using this practice, we also studied two other French phenomena: elision (l'éléphant [le.le.fã]) and $h$-aspiré. We will discuss these data in a future paper.

Task Descriptions 
Picture naming task 1. To select word2, a naming list was generated from a French database of children's lexicon MANULEX (Lété, Sprenger-Charoller and Colé, 2004). Word frequency was controlled using SFI value $(\mathrm{M}=54.94$, Standard Deviation =4.5), provided in the database. The standard frequency index (SFI) is derived from the estimate frequency of the word in a million listed words. It indicates the frequency count of a word in MANULEX. 'A word form or with an SFI of 90 is expected to occur once in every 10 words, one with an SFI of 80 can be expected to occur once in every 100 words, and so forth. A convenient mental reference point is an SFI of 40, the value for a word form or lemma that occurs once in a million words' (Lété, Spenger-Charolles and Colé, 2004, p.162).

All the nouns in the list were 1-3 syllables in length; most were disyllabic (orage [э.ьа3], 'storm'). The items were chosen from a variety of separate semantic categories (e.g. animals, food, body parts and furniture) and had a referent which can be depicted.

To test the phonological phenomena, we generated two contexts word1+word2: article+noun (for liaison) and adjective+noun (for enchaînement). We selected the most frequent articles and adjectives (according to the classification of French contemporary speech by Mallet, 2008). As a result of this choice, we tested the liaison with [z] (e.g. les[z]ours [le.zurs], 'the bears') and enchaînement with [1] (e.g. le minuscule ogre [lə.mi.ny.sky.lo.gь], 'the tiny ogre'), with [s] (e.g. la grosse araignée [la.gьо.sa.ьє.ne], 'the big spider') and with [t] (e.g. la petite orange [la.pə.ti.to.вãz], 'the small orange').

Based on this inventory, we designed 6 pairs of picture cards which depicted an animal or an object named by vowel-initial nouns triggering liaison and enchaînement. The test items were alternated to filler cards at random. The filler cards corresponded to consonant-initial items (le gateau [lə.ga.to], 'the cake'). Additional pairs were used during the training session. Items are presented in appendix (Appendix A).

Writing task. To choose the stimuli for the writing task, we created a database of children's writing forms, analyzing the exercise books and notebooks used in class during the school year ( 855 items). From this database, for word 2 we selected the 12 most frequent vowel-initial nouns in our database $(\mathrm{M}=1.61$, Standard Deviation=1.00). For word2, we decided to use only articles choosing the most frequent article in the classification of French contemporary speech (Mallet, 2008). We combined word 2 with word 1 to create 3

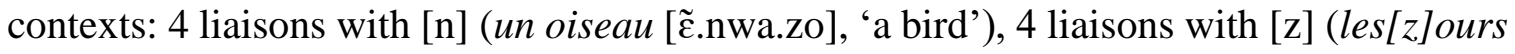
[le.zuss]) and 4 enchaînement with [n], (une autruche [у.not.ву]). We also created 12 filler items (article+noun sequences with consonant-initial nouns le livre [lə.livr], 'the book'). Test and filler items are presented in appendix (Appendix B).

\section{Procedure}

Picture naming task. In the task, we presented 12 card pairs depicting the same animal or object but differing in number (one vs. many). The interviewer named the first card (singular form: l'ours [luвs], 'the bear'; plural form: les petite[z]oranges [le.pə.tit.zэ.ва̃z], 'the small oranges'), then asked the child to name the second card in order to produce the plural or the singular form, triggering liaison (plural form: les[z]ours [le.zuьs], 'the bears') or enchaînement (singular form: la petite[t]orange [la.pə.tit.o.вãz], 'the small orange'). A training session preceded the performance of the task. The training session was completed when the child had learnt how to perform the task, even if some 
cards of the training set were left. The tests items were randomly alternated with fillers (interviewer input: les gâteaux [le.ga.to], 'the cakes' $\rightarrow$ child production: le gâteau [lə.ga.to], 'the cake').

A noteworthy aspect of this task is that for the test items, the interviewer presented the target words in a re-syllabified sequence. As a consequence, the children had to parse the input string and determine word boundaries before naming the second card. Moreover, to name the card, they had to unchain the word sequences to correctly produce the target re-syllabification process.

Children were tested one by one in a quiet room in the school building in 40 minutes' sessions. Oral productions were recorded in a .wav format with a frequency of $44000 \mathrm{~Hz}$ by an audio recorder Zoom H4. The stimuli were randomized to avoid facilitation or strategies.

Writing Task. We provided a pencil, an eraser and a booklet, with a picture on every page (e.g. some oranges), together with an empty line for writing (samples in Appendix C) for every child. For every picture, the tester asked the children to look at the picture and to write down what he was saying. We expected that children would write the article+noun sequence pronounced (les [z]oranges) and then turn the page. The task continued until the booklet was finished. Children were tested in 3 groups generated randomly (two groups of 11 children and one group of 15 children) in 20 minute sessions. The order of the stimuli was randomized for each group to avoid facilitation or strategies.

\section{Results}

\section{Picture Naming Task}

We measured the frequency effect, counting the number of substitutions using [z]initial word 2 in singular sequences (un[z]ours) at the three points (PR, BR and R) and the frequency of word2 based on the SFI index in MANULEX. The number of substitutions and SFI values at the three points are reported in Table 2. We calculated $r$ of Pearson correlations between the number of these substitutions and SFI value. We found a correlation effect in BR $(\mathrm{r}(5)=-0.70, \mathrm{p}<.05)$ and $\mathrm{PR}(\mathrm{r}(5)=-0.89, \mathrm{p}<.05)$ but not in $\mathrm{R}(\mathrm{r}(5)=-$ $0.65, \mathrm{p}=.099$ ). Frequency seems therefore to have an influence on oral productions in prereaders, before reading and writing abilities are developed.

Table 2

Items, frequency values and errors scores in the picture naming task for the three groups

\begin{tabular}{|l|l|l|l|l|}
\hline \multirow{2}{*}{ Items } & \multicolumn{3}{|c|}{ Errors scores : adding a [z] before the noun } \\
& $\begin{array}{c}\text { Frequency } \\
\text { (SFI values) }\end{array}$ & PR & BR & R \\
\cline { 3 - 4 } & & & &
\end{tabular}




\begin{tabular}{|l|c|c|c|c|}
\hline oranges & 53.40 & 6 & 2 & 4 \\
\hline araignées & 47.20 & 3 & 0 & 6 \\
\hline armoires & 45.10 & 0 & 0 & 0 \\
\hline ogres & 0 & 15 & 7 & 8 \\
\hline arrosoirs & 37.95 & 0 & 0 & 2 \\
\hline ours & 67.5 & 2 & 0 & 1 \\
\hline
\end{tabular}

We compared the performance in the picture naming task at the three points. Mean, standard deviation for each phenomenon are presented in Table 3. A one-way repeated measure ANOVA, with scores of errors in oral productions as the dependent variable and with time (PR, BR and R) as independent variable, showed a group difference for liaison $(\mathrm{F} 1(2,72)=5.68, \mathrm{p}<.05, \mathrm{~F} 2(2,4)=9.32, \mathrm{p}<.05)$ but not for enchaînement $(\mathrm{F} 1(2,72)=.55$, $\mathrm{p}=.57, \mathrm{~F} 2(2,4)=24.40, \mathrm{p}=.06)$. ANOVA planned comparison revealed a consistent general decrease of error scores over time only for liaison (BR vs. PR F1(1, $36)=2.40, \mathrm{p}=.19, \quad \mathrm{~F} 2(1,2)=2.81, \quad \mathrm{p}=.35 ; \quad \mathrm{PR} \quad$ vs. $\mathrm{R} \quad \mathrm{F} 1(1, \quad 36)=3.17, \quad \mathrm{p}<.05$, $\mathrm{F} 2(1,2)=12.34, \mathrm{p}<.05)$.

Considering our results, we decided to focus on liaison and we classified errors into two categories: non-realizations of re-syllabification (les ours [le-uвs]) and substitutions (les[n]ours [le.nuss]).

Table 3

Mean, Standard Derivations in the picture naming task

\begin{tabular}{lccccccc}
\multicolumn{2}{c}{$\begin{array}{l}\text { Categories and } \\
\text { groups (n=37) }\end{array}$} & \multicolumn{2}{c}{ Liaison } & \multicolumn{2}{c}{ Enchaînement } & \multicolumn{2}{c}{ Total } \\
\cline { 2 - 8 } & Mean & SD & Mean & SD & Mean & $S D$ \\
\cline { 2 - 8 } Errors & BR & 0.55 & 0.67 & 1.16 & 0.90 & 1.70 & 1.34 \\
\cline { 2 - 8 } & $\mathrm{R}$ & 0.15 & 0.41 & 1.40 & 1.04 & 1.06 & 0.98 \\
\hline
\end{tabular}

One way repeated measure ANOVA, using the scores of non-realizations as dependent variable and using time (PR, BR and $\mathrm{R})$ as independent variable, reveals a group difference $(\mathrm{F} 1(2,72)=12.67 \mathrm{p}<.05, \mathrm{~F} 2(2,4)=6,889, \mathrm{p}<.001)$. The same results are found using the scores of substitutions as dependent variable $(\mathrm{F} 1(2,72)=3.18, \mathrm{p}<.05 ; \mathrm{F} 2(1$, $4)=8.45 \mathrm{p}<.05)$. Planned comparison reveals that whereas the group differences between PR and BR for non-realizations $(F 1(1,36)=2.57, p=.11, F 2(1,2)=1.49, p=.20)$ and substitutions $(\mathrm{F} 1(1,36)=1.18, \mathrm{p}=.18 ; \mathrm{F} 2(1,2)=1.34, \mathrm{p}=.27)$ are not significant, the difference between $\mathrm{BR} / \mathrm{PR}$ and $\mathrm{R}$ is statistically significant for both types of errors (substitutions: $\mathrm{F} 1(1,36)=4.77, \mathrm{p}<.05 ; \mathrm{F} 2(1,2)=3,=.67, \quad \mathrm{p}<.05 ;$ non-realizations : $\mathrm{F} 1(1,2)=4.18, \mathrm{p}<.05, \mathrm{~F} 2(1,2)=10.88 \mathrm{p}<.05)$. Mean, standard deviations on the scores of 
substitutions and non-realizations are presented in Table 4. Despite the error type, the scores decreased between BR and R.

Table 4

Mean, Standard Derivations for liaison in the picture naming task

\begin{tabular}{ccccccc} 
Categories and & \multicolumn{2}{c}{ PR } & \multicolumn{2}{c}{ BR } & \multicolumn{2}{c}{ R } \\
\cline { 2 - 7 } groups (n=37) & Mean & SD & Mean & SD & Mean & SD \\
\hline Substitutions & 0.11 & 0.32 & 0.23 & 0.65 & 0.02 & 0.16 \\
\hline Non-realizations & 0.44 & 0.63 & 0.14 & 0.46 & 0.13 & 0.94 \\
\hline
\end{tabular}

Writing Task

To analyze the results, we considered only the errors associated to the nonidentification of written boundaries. We did not take into account other orthographic mistakes (e.g. the use of $\langle\mathrm{s}\rangle$ for $\langle\mathrm{c}\rangle$, $\langle$ ambulense $\rangle /\langle$ ambulance $\rangle$ or $\langle\mathrm{f}\rangle$ for $\langle\mathrm{ph}\rangle$, <elefant>/<éléphant>).

We classified written production of boundaries into two categories:

- Lexical boundaries scores (LEX): the oral re-syllabified sequences were written correctly. Word boundaries were accurately respected (in liaison: <les ours> 'the bears' and in enchaînement: <une autruche> 'an ostrich').

- Syllabic boundaries scores (SYLL): the oral re-syllabified sequences were transcribed incorrectly. Written word boundaries were defined using oral syllabic boundaries (in liaison: <les zours $\rangle$ with initial $\langle\mathrm{z}\rangle$ for les ours [le.zurs] and in enchaînement: <une nautroche> with initial <n> for une autruche, [y.not.sy]).

Table 5 reported mean scores of LEX and SYLL, considering the two phonological phenomena. We compared the scores of SYLL and LEX by a simple-paired t-test. We found a significant difference between SYLL and LEX in BR $(\mathrm{t}(36)=2.73, \mathrm{p}<.05$; $\mathrm{t}(11)=2.50, \mathrm{p}<.05)$ and $\mathrm{R}(\mathrm{t}(36)=11.399, \mathrm{p}<.001, \mathrm{t}(11)=5.67, \mathrm{p}<.05)$ and a higher mean of LEX than SYLL for BR and R for liaison and enchaînement. We compared the scores of LEX and SYLL between BR and R by a set of paired sample t-test. A significant difference of total scores between the two groups ( $R$ and $B R$ ) were recorded for LEX $(\mathrm{t}(36)=4.595, \mathrm{p}<.001 ; \mathrm{t}(11)=2.45, \mathrm{p}<.05)$ and SYLL $(\mathrm{t}(36)=4.751, \mathrm{p}<.001 ; \mathrm{t}(11)=3.73$, $\mathrm{p}<.05)$. The same results were found comparing BR and $\mathrm{R}$ considering the phonological phenomena tested: for liaison (LEX (BR vs. R): $\mathrm{t}(36)=2.16, \mathrm{p}<.05 ; \mathrm{t}(11)=1.45, \mathrm{p}<.05$; SYLL (BR vs. R): $\mathrm{t}(36)=2.26, \mathrm{p}<.05 ; \mathrm{t}(11)=3.50$, $\mathrm{p}<.05)$ and enchaînement (LEX (BR vs. $\mathrm{R}), \mathrm{t}(36)=8.061, \mathrm{p}<.001 \mathrm{t}(11)=4.85, \mathrm{p}<.05$; SYLL (BR vs. R): $\mathrm{t}(36)=9.301, \mathrm{p}<.001$; $\mathrm{t}(11)=5.22, \mathrm{p}<.05)$. As shown in Table 5, the scores of SYLL decreased between BR and $\mathrm{R}$, despite of the phenomenon studied. At the same time, LEX increased in R. As children developed reading and writing skills, they were better able to identify the written word boundaries of the word 1 and word 2 . 
Table 5

Mean, Standard Derivations in the writing task

\begin{tabular}{lcccccccc}
\multicolumn{2}{l}{$\begin{array}{l}\text { Categories and N } \\
\text { groups }\end{array}$} & \multicolumn{2}{c}{ Liaison } & \multicolumn{2}{c}{ Enchaînement } & \multicolumn{2}{c}{ Total } \\
\cline { 3 - 9 } LEX & BR & 37 & 5.16 & 2.29 & 4.21 & 0.83 & 7.31 & 3.04 \\
\cline { 2 - 8 } & R & 37 & 6.57 & 1.99 & 7.47 & 0,44 & 10.44 & 2.35 \\
\hline \multirow{2}{*}{ SYLL } & BR & 37 & 2.83 & 2.07 & 3.57 & 0.88 & 4.67 & 3.40 \\
\cline { 2 - 8 } & R & 37 & 1.43 & 2.29 & 0.31 & 0.44 & 1.59 & 2.35 \\
\hline
\end{tabular}

\section{Cross-Task Comparison}

To highlight the possible influence of literacy in oral productions, we compared the results of the picture naming task and the writing task in $\mathrm{R}$ for liaison. For the crosscomparison, we decided to exclude the analyses of enchaînement as the number of errors in oral productions stayed stable.

First, we found a positive correlation between the picture naming task and the writing task $(\mathrm{r}(36)=0.396, p<.001)$ : the scores of correct productions of re-syllabified sequences in the picture naming task correlated with LEX in the writing task: the scores of correct oral productions increased with the scores of LEX, which means that the identification of lexical boundaries in the writing task improved as the correct oral productions of re-syllabified sequences improved.

Moreover, in $\mathrm{R}$ the scores of non-realizations of liaison in the picture naming task correlate negatively with LEX $(\mathrm{r}(36)=-0.546, p<.001)$ : the scores of non-realizations decreased together with the increase of LEX. The correct identification of lexical boundaries in written sequences links with the decrease of non-realizations of re-syllabified sequences in oral productions.

\section{Discussion}

In the current longitudinal study, we compared the word segmentation process in re-syllabified sequences involving liaison and enchaînement in the same group of children testing them at three points: when they are pre-readers, beginning-readers and readers. For enchaînement, no difference was found at the 3 points. For liaison, our results of the picture naming task showed that French children, before becoming literate, had more difficulties in word segmentation, reflected in substitutions (les nours [le.nuss], for les ours [le.zubs] 'the bears') and non-realizations of re-syllabification (les ours [le uss], for les ours [le.zuss]). The number of substitutions and non-realizations stayed stable in the early stage of literacy acquisition but decreased together with literacy acquisition progresses.

Our results concerning the number of substitutions are almost in line with our expectations for liaison. Substitutions decrease after age 5 as already shown by all the longitudinal and transversal studies on liaison acquisition presented in the introduction. 
However, in our research, we noticed that substitutions did not completely vanish as inferred from previous studies (Chevrot, Dugua, Harnois-Delpiano, Siccardi \& Spinelli, 2013). For non-realizations, data analysis allows us to negate our hypothesis based on the literature (Basset, 2000). After age 5, we noticed that the score of non-realizations decreased between beginning readers and readers and was not stable as we thought.

As initially supposed, frequency plays a central role in oral productions only until 5 or 6 years of age, before literacy development. We could think that frequency is an important variable determining the acquisition of lexical boundaries before age 5 . The Usage-based theory provides a valid explanation to the acquisition of liaison and enchaînment phenomena when children were not already readers and processed only oral inputs. A word 2 more frequent in its plural form, compared to the singular form, is more available in plural sequences (e.g. les[z]éléphants) than in the singular sequences (ex. un [n] éléphant). Consequently, children process this word 2 as a $[\mathrm{z}]$ initial word, producing a higher number of substitutions (un[z]éléphant for un[n]éléphant).

However, when children develop literacy skills, the errors in oral productions cannot be explained by the frequency anymore. These results accord with the Chevrot et al. study (in publication) which found that frequency by itself couldn't explain word boundaries acquisition of resyllabified sequences after age 5. As Chevrot et al., we supposed that another major variable participates to this acquisition: literacy.

To understand if literacy is involved in oral productions and word boundaries acquisition after 5 years of age, we proposed a writing task. In this task, we found that beginning readers can correctly identify lexical written boundaries in re-syllabified sequences and that this competence improved when they became readers. These results were not unexpected. Since children improved their literacy skills attending French classes during first and second grade, they learned how to write word1+word 2 sequences and to identify written lexical boundaries of articles, adjectives and nouns.

Considering that liaison oral productions showed a particular developmental pattern in the three time periods we decided to focus on this particular phenomenon. To understand the connection between literacy and oral productions for liaison, we proposed a cross-task comparison.

The results of our cross-task comparison showed that in readers the identification of written boundaries correlate with the increase of correct oral productions and also with the decrease of non-realizations. Hence, if prior to literacy acquisition, frequency is an important variable which influences liaison productions, in readers the knowledge of written boundaries and orthographic forms could be a plus factor guiding children to selfcorrect product oral re-syllabified sequences, avoiding substitutions and non-realizations. Thus, as children can correctly write re-syllabified sequences, they can also correctly perform them orally. Moreover, cross-task comparison told us that literacy was not responsible for readers' non-realizations as we proposed in our hypothesis. On the contrary, the knowledge of written boundaries seemed to have a positive effect in oral productions: the scores of non-realizations decreased as the knowledge of written lexical boundaries increased. Writing activities contribute in segmentation of re-syllabified sequences, helping children to solve difficulties with re-syllabified sequences and lexical boundaries.

Based on our results, we think that the development of literacy skills due to writing and reading activities at school is related to the appropriation of a phonological representation. Literacy might help children to treat word 1 and word 2 in liaison sequences 
since it helps to distinguish the two phonological representations associated with the lexical consonant and with the liaison. In the introduction, we presented the phonological differences between a lexical consonant and a LC, proposing two autosegmental representations. If in liaison representation, the LC is a double-floating segment, in a nonliaison sequence, the lexical consonant is not floating but it is grounded in skeletal and syllabic points. We could imagine that writing and reading activities help children tell the differences between these two consonants as they contribute to acquire the specific phonological representation of LC together with its phonological peculiar properties. If the lexical consonant is always the initial consonant used to pronounce and write word 2 (the $\mathrm{z}$ [z] in zèro), the LC has a different behavior. In writing it appears in word1, but in reading it has to be pronounced as the syllabic initial of word2 (e.g. the $\mathrm{z}$ [z] les[z]éléphants). Considering the two phonological models and our results, we suggest that learning how to write word 1 might allow children to fix the segmental content of LC, as the phonetic information (e.g. [z]) was represented by written letters which have a concrete content (e.g. the $\langle\mathrm{s}\rangle$ at the end of les). Moreover, writing could help to embed the LC at the end of word1 in its phonological representation, linking this segmental information to the skeletal position. Thus, we could explain the decrease of the number substitutions in oral productions in readers. Similarly, learning to read the sequences of word1+word2, resyllabifying the LC consonant ending word1 at the beginning word2, could help them to reinforce and set the link to the syllabic attack of word2. Therefore, thanks to the knowledge of written boundaries and the literacy skills developed in writing and reading activities, children could better chain word1 and word2 sequences, performing liaison correctly, avoiding non-realizations.

The idea that literacy could shape and fix phonological representations already emerged in some previous works analyzing orthographic patterns and phonological properties of Italian (Ruvoletto, 2011) and French (Chevrot, Beaud \& Varga, 2000), leading Peerman, Dufour and Burt (2009) to think that "the orthographic properties of words may partially shape how phonological representation are organized" (p.367).

From this point of view non-realizations and substitutions are not errors but attempts made by children to get closer to the target forms. These attempts highlight the limit of an acquisition strategy of lexical boundaries and resyllabified sequences based only on oral productions and frequency. After age 5, children who could use literacy to approach target form and set phonological representation, could also correctly produce liaison and enchaînement.

\section{Conclusions}

The current study aims to evaluate the frequency effect and the role of literacy acquisition in word segmentation after 5 years of age. We measured the frequency effect in oral productions and we discovered that it took place only in beginning readers and prereaders performances. No effect was recorded for readers in second grade who had developed literacy skills. Our results accord with the previous studies presented in the literature, confirming that frequency effect stops to operate in productions of re-syllabified sequences after age 7. To understand if literacy is a plus factor participating in word segmentation after this age, we conducted a writing task. The results of the writing task showed that French children in primary school preferred to write re-syllabified sequences using the correct lexical forms (<les elephants >, 'the elephants') rather than using syllabic 
units (<les zelephants> for <les elephants>). They were aware of written word segmentation and lexical boundaries in sequences despite of the phonological phenomena and this awareness improved together with literacy progresses.

The cross-task comparison helped to clarify the relationships between literacy and oral production in readers, when no frequency effect was recorded. We established that the stability of non-realizations reported in the literature could not be caused by a negative effect of literacy in itself as predicted in our hypothesis. At age 7, literacy does not drive children to unchain words, treating them as separate blocks. On the contrary, considering our results for liaison, the knowledge of written boundaries seems to be a helpful tool to solve non-realizations, setting phonological representation of the segmental information of LC and fixing its syllabic positions in this representation.

We do not yet know if the resolution of non-realizations is connected to the written representation which in turn influences phonological representation and oral realizations exclusively. It is possible that literacy-related skills (as attention, memory and metaphonological skills) help to resolve language problems in the production of liaison. For these reasons, it is powerful to consider literacy as a plus factor that plays a role in word segmentation in French children after 7 years of age together with other skills and knowledge.

This research also allows us to affirm that liaison and enchaînement cannot be phonologically treated as the same kind of phenomenon as oral acquisition developed in two different ways. Different phonological representations for these two phenomena should be provided as already shown by autosegmental phonological models (Encrevé, 1983; Wauquier \& Braud, 2005). Nonetheless, the two phenomena entail re-syllabification; they show different patterns in oral acquisition. In the picture-naming task, liaison attempts decrease but enchaînement attempts stay stable. However, the written knowledge of liaison and enchaînement sequences in writing follow the same patterns, as word 1 and word 2 are separated correctly in beginning readers and readers. These differences could depend on the phonological nature of the two phenomena but also on the syntactic context proposed for the writing task. In the writing task, we asked to write article+noun sequences for enchaînement and liaison whereas in the picture-naming task we asked to produce adjective+ noun sequences only for enchaînement. Further research is needed in order to clarify the acquisition and the characteristics of these two phenomena.

This is the first longitudinal study that investigates the acquisition of resyllabification phenomena after the age of 6 . Moreover, it is the only study that takes literacy into account in the analysis of word segmentation in French. As this is an initial study, the results could be refined and other tasks should be designed to better understand the mutual influences of literacy and oral word segmentation.

\section{References}

Babineau, M. \& Shi, R. (2011). Processing of French liaisons in toddlers. In BUCLD 35: Proceedings of the 35th annual Boston University conference on language development (pp.25-37). Boston, MA: Cascadilla Press.

Bassano, D., Maillochon, I. \& Mottet, S. (2008). Noun grammaticalization and determiner use in French children's speech: A gradual development with prosodic and lexical influences. Journal of Child Language, 35(2), 403-438. 
Basset, B. (2000). La liaison à 3, 7 et 11 ans: description et acquisition (Unpublished master thesis). University of Grenoble 3, Grenoble, France.

Bybee, J. (2001a). Phonology and language use. Cambridge, UK: Cambridge University Press.

Bybee, J. (2005). La liaison : effets de fréquence et constructions. Langages, 158, 24-37.

Braud, V. (2003). Acquisition de la prosodie chez des enfants francophones: les phénomènes de troncations (Unpublished doctoral dissertation). University of Nantes, Nantes, France.

Burt, J. S. (2006), What is orthographic processing skill and how does it relate to word identification in reading? Journal of Research in Reading, 29(4), 400-417.

Chevrot, J.-P., Beaud, L. \& Varga, R. (2000). L'apprentissage des unités phonologiques variables: l'exemple du /R/ post-consonantique final en français. Linx, 42, 89-100.

Chevrot, J.-P., Chabanal, D. \& Dugua, C. (2007). Pour un modèle de l'acquisition des liaisons basé sur l'usage: trois études de cas. Journal of French Language Studies, 17(1), 103-128.

Chevrot, J.-P., Dugua, C. \& Fayol, M. (2009). Liaison, word segmentation and construction in French: A usage-based account. Journal of Child Language, 36 (3), 557-596.

Chevrot, J.-P., Dugua, C., Harnois-Delpiano, M., Siccardi, A. \& Spinelli, E. (2013). Liaison acquisition: Debates, critical issues, future research. Language Sciences, 39, 83-94.

Chevrot, J.-P., \& Fayol, M. (2001). Acquisition of French Liaison and Related Child Errors. Selected paper of the 8th Congress for the Study of Child Language, San Sebastian, julliet 1999.

Chevrot, J.-P., Siccardi, A., Parisse, C., \& Spinelli, E (in press). Multiword sequences and phonological variants in the lexicon: What can we learn from the acquisition of prenominal liaison in French?

Cossu, G., \& Marshall, J.C. (1985). Dissociation between reading and written spelling in two Italian children: Dyslexia without dysgraphia?. Neuropsychlogia, 23(5), 697 700.

Côté, M.-H. (2014). Liaison et assibilation en français laurentien. Dans C.

Soum-Favaro, A. Coquillon \& J.-P. Chevrot (Eds.). La liaison: approches contemporaines (pp. 8-26). Bern, Switzerland: Peter Lang.

Curtin, S., Mintz, T.H. \& Christiansen, M.H. (2005). Stress changes the representational landscape: Evidence from word segmentation. Cognition, 96(3), 233-262.

Cutler, A., \& Carter, D.M. (1987). The predominance of strong initial syllables in the English vocabulary. Computer Speech and Language, 2(3-4), 133-142.

Cutler, A., \& Norris, D. (1988). The role of strong syllables in segmentation for lexical access. Journal of Experimental Psychology: Human Perception and Performance, 14(1), 113-121.

Cutler, A., \& Otake, T. (1994). Mora or phoneme? Further evidence for language-specific listening. Journal of Memory and Language, 33(6), 824-844.

Delattre, P. (1965). Comparing the phonetic features of English, French, German and Spanish. Heidelberg, Germany: Jumius Gross Verlag.

Demuth, K., \& Tremblay, A. (2008). Prosodically-conditioned variability in children's production of French determiners. Journal of Child Language, 35(1), 99-127. 
Di Cristo, A. (1998). Intonation in French. Dans D. Hirst, \& A. Di Cristo (Eds.), Intonation Systems: A Survey of Twenty Languages (pp. 195-218). Cambridge, UK: Cambridge University Press.

Dijkstra, T., Fieuws, F., \& Roelofs, A. (1995). Orthographic effects on phoneme monitoring. Canadian Journal of Experimental Psychology, 49(2), 264-271.

Dugua, C. (2006). Liaison, segmentation lexicale et schémas syntaxiques entre 2 et 6 ans. Un modèle développemental basé sur l'usage. Thèse de doctorat, Université Stendhal, Grenoble III.

Dugua C., \& Chabanal, D. (2006). Acquisition de la liaison chez l'enfant francophone, formes lexicales des mots2. Poster lors du Colloque International : JEP (Journées d'Etude sur la Parole. Dinard, France, (CD -rom).

Dugua, C., Chevrot, J.-P. \& Fayol, M. (2006). Liaison, segmentation des mots et schémas syntaxiques entre 2 et 6 ans: un scénario développemental. In D. J. Duché \& C. L. Gérard (Eds.), Entretiens de Bichat : Orthophonie (pp.230-244). Paris, France : Expansion Scientifique Française.

Duncan, L.G., Seymour, H.K. \& P., Hill, S. (2000). A small-to-large unit progression in metaphonological awaereness and reading?. The Quarterly Journal of Experimental Psychology, 53 (4), 1081-1104.

Ehri, L.C., \& Wilce, I. (1980). The influence of orthography on readers' conceptualization of the phonemic structure of words. Applied Psycholinguistics, 1(4), 371-385.

Encrevé, P. (1983). La liaison sans enchaînement. Actes de la recherche en sciences sociales, 46, 39-66.

Encrevé, P. (1988). La liaison avec et sans enchaînement: phonologie tridimensionelle et usage du français. Paris, France: Seuil.

Feifer, S. G. (2013, December 3). The Neuropsychology of Reading, Writing and Mathematics: A Framework for Effective Intervention [Web]. School Neuropsychology Certificate Program.

Goldsmith, J. (1990). Autosegmental and metrical phonology. Oxford, UK: Basil Blackwell.

Goyet, L., de Schonen, S. \& Nazzi, T. (2010). Words and syllables in fluent speech segmentation by French-learning infants: An ERP study. Brain Research, 1332, $75-89$.

Goswami, U. (2000). Phonological representations, reading development and dyslexia: Towards a cross-linguistic theoretical framework. Dyslexia, 6(2), 133-151.

Hallé, P., Chéreau, C. \& Segui, J. (2000). Where is the /b/ in "absurde" [apsyrd]? It is in French listeners' minds. Journal of Memory and Language, 43, 618-639.

Jusczyk, P.W., Houston, D.M. \& Newsome, M. (1999). The beginning of word segmentation in English-learning infants. Cognitive Psychology, 39(3-4), 159207.

Kaye, J.D., \& Lowenstamm, J. (1984). De la syllabicité. In F.Dell, D.Hirst and J.-R. Vergnaud (Eds.), Formes sonores du lanagage: structure des representations en phonologie (pp. 123-159). Paris, France: Hermann.

Lété, B., Sprenger-Charolles, L. \& Colé, P. (2004). MANULEX: A grade-level lexical database from French elementary-school readers. Behavior Research Methods, Instruments, and Computers, 36(1), 156-166. 
Mallet, G. (2008). La liaison en français: descriptions et analyses dans le corpus PFC (Doctoral dissertation). University of Paris Ouest-Nanterre-La Défense, Nanterre, France.

Nardy, A., \& Dugua, C. (2011). Le role de l'usage sur le développement des constructions nominales chez les enfants pré-lecteurs. Traveaux de linguistique, 1, 129-148.

Nation, K., \& Hulme, C. (2011). Learning to read changes children's phonological skills: Evidence from a latent variable longitudinal study of reading and non-word repetition. Developmental Science, 14(4), 649-659.

Nazzi, T., Iakimova, I., Bertoncini, J., Frédonie, S. \& Alcantara, C. (2006). Early segmentation of fluent speech by infants acquiring French: Emerging evidence for cross-linguistic differences. J. Mem. Lang., 54(3), 283-299.

Peereman R., Dufour S., Burt J. S. (2009). Orthographic influences in spoken word recognition: The consistency effect in semantic and gender categorization tasks. Psychonomic Bulletin \& Review, 16(2), 363-368.

Perre, L., Midgley, K. \& Ziegler, J. C. (2009). When beef primes reef more than leaf: Orthographic information affects phonological priming in spoken word recognition. Psychophysiology, 46(4), 739-746.

Pinnell, G.S., \& Fountas, I. (2004). Word Study Lessons: Phonics, Spelling, and Vocabulary. Portsmouth, NH: Heinemann Press.

Pulgram, E. (1970). Syllable, Word, Nexus, Cursus. Paris, France: The Hague.

Ruvoletto, S. (2011). Fonologia autosegmentale e alfabetizzazione emergente: modello multilineare e geminate tra scrittura pre-convenzionale e formalizzata (Unplublished master thesis, University of Padova, Padua, Veneto, Italy.

Saffran, J.R., Newport, E. \& Aslin, R. (1996). Word segmentation: The role of distributional cues. Journal of memory and language, 35(4), 606-621.

Seidenberg, M.K. \& Tanenhaus, M. S. (1979). Orthographic effects in rhyme and monitoring. Journal of Experimental Psychology: Human Learning and Memory, 5(6), 546-554.

Tomasello, M. (2003). Constructing a Language: A Usage-Based Theory of Language Acquisition. Cambridge, MA: Harvard University Press.

Wauquier-Gravelines, S. (2004). Les liaisons dangereuses. Psycholinguistique et phonologie : une interface complexe. In L. Ferrand \& J. Grainger (Eds.), Psycholinguistique cognitive, Essais en l'honneur de Juan Segui (pp. 93-105), Bruxelles, Belgium: De Boeck Université, Collection Neurosciences et Cognition.

Wauquier, S. (2009). Acquisition de la liaison en L1 et L2 : stratégies phonologiques ou lexicales? AILE Lia, 2, 93-130.

Wauquier, S. (2010). Acquisition de la phonologie « du » français: des usages au système. Revue Langue Française, 1-20.

Wauquier, S. (2013). Convergence and divergence in the acquisition of French liaison by native and non-native speakers, a review of existing data and avenues for future research, Language, Interaction and Acquisition, 4(2), 160-18.

Wauquier - Gravelines S. \& Braud, V. (2005). Proto-déterminant et acquisition de la liaison obligatoire en français. Langages, 158, 53-65.

Wauquier, S., \& Shoemaker, L.M. (2013). Convergence and divergence in the acquisition of French liaison by native and non-native speakers: A review of existing data and 
avenues for future research. Language, Interaction and Acquisition, 4(2), 161189.

Ziegler, J.C. \& Goswami, U. (2005). Reading acquisition, developmental dyslexia, and skilled reading across languages: A psycholinguistic grain size theory. Psychological bulletin, 131(1), 3.

Ziegler, J.C. \& Muneaux, M. (2007). Orthographic facilitation and phonological inhibition in spoken word recognition: a developmental study. Psychonomic Bulletin and Review, 14, 75-80.

Author Biography

Samantha Ruvoletto is currently a lecturer in Linguistics at Lorraine University (France). She earned her Ph.D in Linguistics from the University of Paris 8 (France) in 2016, working with Prof. Sophie Wauquier. In her thesis work, she highlighted the relationships between language and literacy acquisition, exploring how French children acquire lexical boundaries in presence of resyllabification (as, for instance, liaison). 
Appendix A: Material from the picture naming task

\begin{tabular}{|c|c|c|c|}
\hline \multicolumn{4}{|c|}{ Test } \\
\hline Phenomenon tested & \multicolumn{2}{|c|}{ Input } & Expected answer \\
\hline \multirow{3}{*}{ Liaison } & \multicolumn{2}{|c|}{ l'ours [luss], 'the bear' } & les ours [le.zurs], 'the bears' \\
\hline & \multicolumn{2}{|c|}{$\begin{array}{c}\text { l'armoire [las.mwar], 'the } \\
\text { closet' }\end{array}$} & $\begin{array}{c}\text { les armoires [le.zas.mwar], 'the } \\
\text { closets', }\end{array}$ \\
\hline & \multicolumn{2}{|c|}{$\begin{array}{l}\text { l'arrosoir [la.во.zwab], 'the } \\
\text { watering can' }\end{array}$} & $\begin{array}{c}\text { les arrosoirs [le.za.во.zwar], 'the } \\
\text { watering cans' }\end{array}$ \\
\hline \multirow{3}{*}{ Enchaînement } & \multicolumn{2}{|c|}{$\begin{array}{c}\text { les minuscules ogres } \\
\text { [le.mi.ny.skyl.zogr], 'the small } \\
\text { ogres' }\end{array}$} & $\begin{array}{c}\text { le minuscule ogre } \\
\text { [lə.mi.ny.sky.logr], 'the small } \\
\text { ogre' }\end{array}$ \\
\hline & \multicolumn{2}{|c|}{$\begin{array}{l}\text { les petites oranges } \\
\text { [1e.pə.tit.zo.sãz], 'the small } \\
\text { oranges' }\end{array}$} & $\begin{array}{l}\text { la petite orange } \\
\text { [la.pə.ti.to.sãz], 'the small } \\
\text { orange' }\end{array}$ \\
\hline & \multicolumn{2}{|c|}{$\begin{array}{l}\text { les grosses araignées } \\
\text { [le.gro.za.ke.ne], 'the big } \\
\text { spiders' }\end{array}$} & 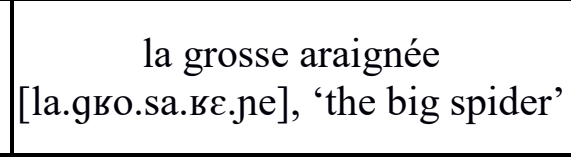 \\
\hline \multicolumn{4}{|c|}{ Fillers } \\
\hline \multicolumn{2}{|c|}{ La pomme, 'the apple' } & \multicolumn{2}{|r|}{ Les pommes, 'the apples' } \\
\hline \multicolumn{2}{|c|}{ Le cahier, 'the notebook' } & \multicolumn{2}{|r|}{ Les cahiers, 'the notebooks' } \\
\hline \multicolumn{2}{|c|}{ La cerise, 'the cherry' } & \multicolumn{2}{|r|}{ Les cerises, 'the cherries' } \\
\hline \multicolumn{2}{|c|}{ Les gâteaux,'the cakes' } & \multicolumn{2}{|r|}{ Le gâteau, 'the cake' } \\
\hline \multicolumn{2}{|c|}{ Les lapins, 'the rabbits' } & \multicolumn{2}{|r|}{ Le lapin, 'the rabbit' } \\
\hline \multicolumn{2}{|c|}{ Les parapluies, 'the umbrellas' } & \multicolumn{2}{|r|}{ Le parapluie, 'the umbrella' } \\
\hline \multicolumn{4}{|c|}{ Training } \\
\hline \multicolumn{2}{|c|}{ le bateau, 'the boat' } & \multicolumn{2}{|r|}{ les bateaux, 'the boats' } \\
\hline \multicolumn{2}{|c|}{ la fleur, 'the flower' } & \multicolumn{2}{|r|}{ les fleurs, 'the flowers' } \\
\hline \multicolumn{2}{|c|}{ la maison, 'the house' } & \multicolumn{2}{|r|}{ les maisons, 'the houses' } \\
\hline \multicolumn{2}{|c|}{ un gros poisson, 'a big fish' } & \multicolumn{2}{|c|}{ des gros poissons 'some big fishes' } \\
\hline \multicolumn{2}{|c|}{ un grand chien, 'a big dog' } & \multicolumn{2}{|c|}{ des grands chiens, 'some big dogs' } \\
\hline \multicolumn{2}{|c|}{ les stylos, 'the pens' } & & le stylo, 'the pen' \\
\hline les livres, ‘ & the books' & & le livre, 'the book' \\
\hline les cochons & s, 'the pigs' & & le cochon, 'the pig' \\
\hline des petits chats, ' & 'some small cats' & & in petit chat, 'a small cat' \\
\hline
\end{tabular}


Appendix B: Items from the writing task

\begin{tabular}{|c|c|}
\hline \multicolumn{2}{|r|}{ Tests } \\
\hline Items & Phenomena \\
\hline les ours 'the bears' & \multirow{7}{*}{ Liaison } \\
\hline un oiseau, 'a bird' & \\
\hline un orage, 'a storm' & \\
\hline les affiches, 'the posters' & \\
\hline un ananas, 'a pineapple' & \\
\hline les oranges, 'the oranges' & \\
\hline un igloo, 'an igloo' & \\
\hline une autruche, 'an ostrich' & \multirow{5}{*}{ Enchaînement } \\
\hline des ailes, 'the wings' & \\
\hline une épée, 'a sword' & \\
\hline une île, 'an island' & \\
\hline une ambulance, 'an ambulance' & \\
\hline \multicolumn{2}{|r|}{ Fillers } \\
\hline \multicolumn{2}{|c|}{ Les zéros, 'the zeros' } \\
\hline \multicolumn{2}{|c|}{ Les zèbres, 'the zebras' } \\
\hline \multicolumn{2}{|c|}{ Les zoos, 'the zoos' } \\
\hline \multicolumn{2}{|c|}{ Un nez, 'a nose' } \\
\hline \multicolumn{2}{|c|}{ Un nid, ' a nest' } \\
\hline Un $n$ & avire, 'a ship' \\
\hline
\end{tabular}


Appendix C: Sample from the booklet used for the writing task
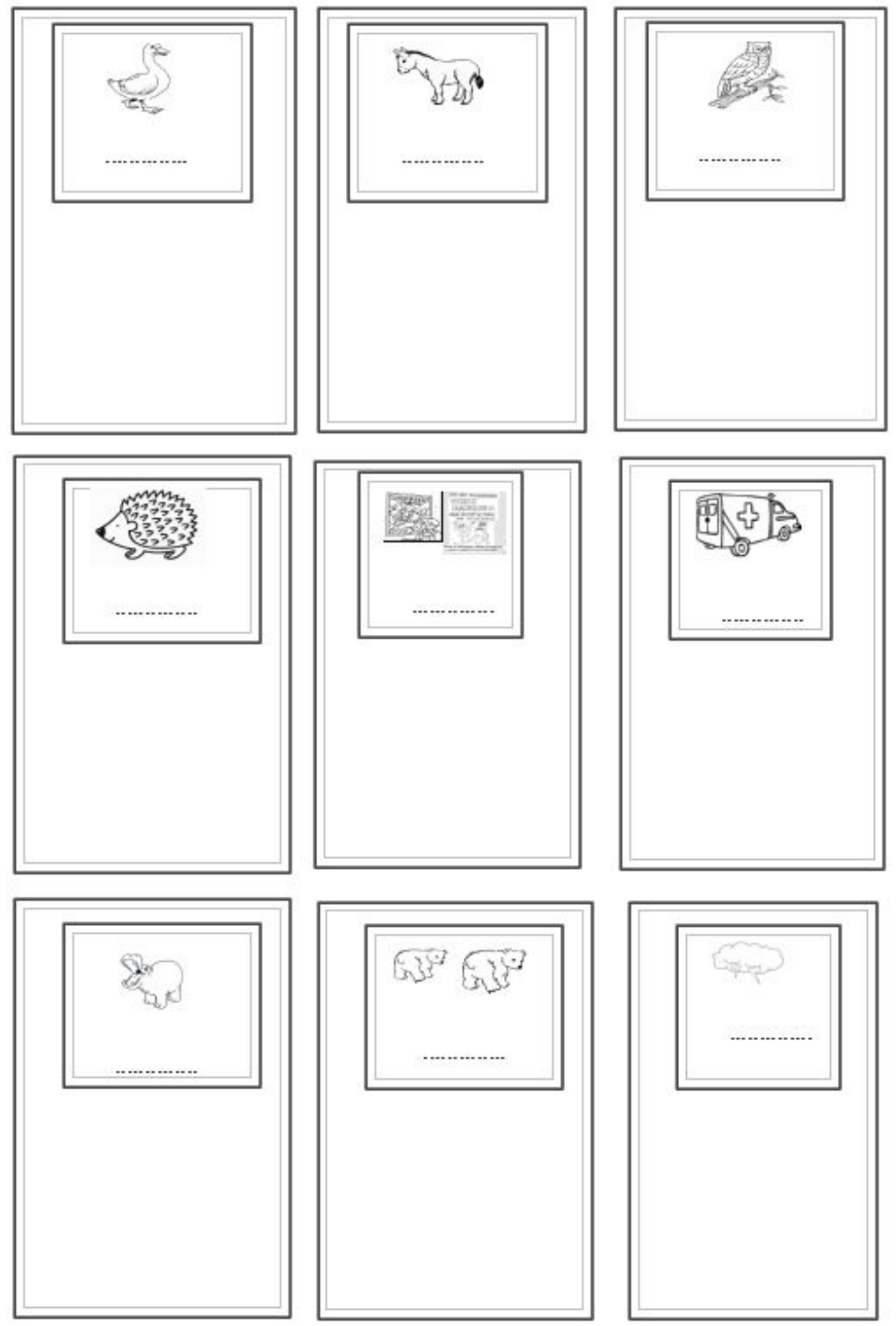

Language and Literacy

Volume 21, Issue 4, 2019

Page 116 